\title{
CHARACTERIZATION OF VOLATILE COMPOUNDS IN THE ESSENTIAL OIL OF SWEET LIME (Citrus limetta Risso)
}

\author{
María C. Colecio-Juárez1, Rubria E. Rubio-Núñez², José E. Botello-Álvarez, \\ Gloria M. Martínez-González ${ }^{1}$, José L. Navarrete-Bolaños ${ }^{1}$, and Hugo Jiménez-Islas ${ }^{\text {* }}$
}

\begin{abstract}
The essential oil of citrus fruit contains components pleasant sensory characteristics that are appreciated in food, pharmaceutical, and cosmetics industries. In the case of sweet lime (Citrus limetta Risso), is necessary to characterize the essential oil components, to identify potential uses of this fruit. The essential oil of sweet lime was obtained from lime flavedo in four different maturation stages. Steam distillation was employed and then compared with hexane extraction. The identification of the components in the essential oil was carried out by gas chromatography and mass spectrometry. A total of 46 components were found in the essence of lime, among which the highest concentration of compounds present were aldehydes such as limonene. Linalool, sabinene, and bergamol were more abundant than in other varieties. The best extraction method was steam distillation, and the concentrations in stage III from the main terpenic portion were d-limonene with $74.4 \%$, bergamol with $8.23 \%$, and $\beta$-pinene with $7.62 \%$.
\end{abstract}

Key words: Sweet lime, Citrus limetta, essential oil, steam distillation, maturation stages.

$\mathrm{T}$ he citrus species are a potential source of valuable oil which might be utilized for edible and other industrial applications (Anwar et al., 2008), and essential oils are broadly used as pharmaceutical components, in nutritious supplements, and for cosmetic industry and aromatherapy (Kondo et al., 2000; Misharina and Samusenki, 2008). Essential oils are a product obtained from vegetable raw materials (Berger, 2007). The essences are complex mixtures whose composition may include volatile terpenic compounds, which have the formula $\left(\mathrm{C}_{5} \mathrm{H}_{8}\right)_{\mathrm{n}}$, where the compounds are monoterpenes if $\mathrm{n}=2$, sesquiterpenes when $n=3$, diterpenes when $n=4$, etc. The terpenoids are oxygenated derivatives of terpenes, which may contain hydroxyl or carbonyl groups (Smith et al., 2001). These are secondary metabolites in plants (Mazen, 2002) and are responsible for the characteristic aroma on the fruit. The terpenoids are synthesized in the flavedo, an outer layer that forms part of the exocarp or peel. This section of peel contains the essential oil in circular cavities (oil glands) (Berger, 2007). The production is approximately $1 \mathrm{~mL}$ essential oil per $100 \mathrm{~cm}^{2}$ exocarp (Mazen, 2002).

\footnotetext{
${ }^{1}$ Instituto Tecnológico de Celaya, Laboratorio de Bioingeniería y Departamento de Ingeniería Química-Bioquímica, Av. Tecnológico y Antonio García Cubas s/n. 38010. Celaya, Guanajuato, México. "Corresponding author (hugo.jimenez@itcelaya.edu.mx).

${ }^{2}$ Universidad Tecnológica de Salamanca, Carrera de Química, Área Ambiental, Boulevard Morelos 1900, Col. El Pirul, Salamanca, Guanajuato, México.

Received: 2 August 2011.

Accepted: 18 May 2012.
}

The composition of the citric fruits is generally composed of $90 \%$ terpenes, $5 \%$ oxygenated compounds, and less than $1 \%$ non-volatile compounds such as waxes and pigments (Kondo et al., 2000). D-Limonene, the most abundant terpene has antimicrobial properties, primarily the exhibition of antibacterial activity against Grampositive bacteria, and also increases the effectiveness of sodium benzoate as a preservative (Murdock and Allen, 1960; Roger et al., 1970; Berger, 2007). Among the monoterpenes are citral which has antifungal properties, linalool which has fungistatic properties, and linalool, limonene and $\beta$-pinene, all of which have a repellent effect on Drosophila melanogaster (Yamasaki et al., 2007). The essential oils may be extracted through different methods whose use depends on the desired yield and quality and the location of the oil glands (Mazen, 2002). Some of these methods are: steam distillation, cold pressing, peel compression, hydrodistillation, and supercritical fluid extraction (Mazen, 2002; Frizzo et al., 2004; Gil and Sáez, 2005; Atti-Santos et al., 2005). After the extraction, the identification of the compounds in the oil is important; chromatography is the most-used alternative (Mondello et al., 2003).

In the analysis and comparison of the essential oils of lemon (Citrus aurantifolia Swingle), bergamot (Citrus bergamia Risso), mandarin (Citrus deliciosa Tenore), sweet orange (Citrus sinensis L. Osbeck) and bitter orange (Citrus aurantium L), it was found that most of the compounds in these citric essential oils are terpenes, such as $\alpha$-thujene, $\alpha$-pinene, camphene, sabinene, 
$\beta$-pinene, myrcene, $\alpha$-terpinene, $p$-cymene, linalool, and d-limonene; this last terpene was the most abundant compound in the four citric fruits, with a concentration of $90 \%$ in sweet orange and bitter orange. Likewise, each citrus fruit has particular components present in minor quantities; these components differ between fruits and can be used in identifying the various oils and controlling their quality and authenticity (Mondello et al., 2003). The sweet lime, according to W.T. Swingle classification (Nicolosi, 2007), belongs to Citrus gender, limetta species, Risso variety, Auranciaceas subfamily and Rutaceae family. In Mexico, the sweet lime does not have as much importance as the amount attached to the diverse lemon varieties, and it still lacks commercial value, although it is produced in 14 states of the Mexican Republic. Additionally, this crop has begun to disappear from the state of Guanajuato, due to a lack of marketing and incorporation into products that can be made easily available on the market.

An important step in the study of sweet lime is the characterization of the components of its essential oil for the purpose of identifying potential uses of the fruit. In a recent research, Perez et al. (2010) report that sweet lime (Citrus limetta Risso) leaves extract antagonizes the hypertensive effect of angiotensin II, suggesting an important bioactive capability of sweet lime. Few studies have been focused on the extraction and analysis of the essential oil of the sweet lime. In the present work, the essential oil of sweet lime was obtained by steam distillation and extraction with hexane in different stages of maturity; to identify main compounds by gas chromatography and mass spectrometry.

\section{MATERIALS AND METHODS}

\section{Plant material}

Nine sweet lime (Citrus limetta) samples (three fruits per sample) were collected from the region of San Juan de la Vega, Celaya, Guanajuato, Mexico (20 38'00' $\left.\mathrm{N}, 100^{\circ} 46^{\prime} 00^{\prime} \mathrm{W}\right)$. The sweet lime juice was extracted and characterized physicochemically for their amount of soluble solids ( ${ }^{\circ}$ Brix) (JAOAC, 1983) and titration acidity (expressed as percentage of citric acid) (AOAC, 1990). The limes were weighed, peeled, squeezed, and classified according to their maturity stage using as a base the relationship between ${ }^{\circ}$ Brix and the acidity expressed in grams of citric acid per $100 \mathrm{~mL}$ of juice (Louche et al., 2000). The fruit's maturity stages were defined as I, II, III, and IV conform to the soluble solids content was increased and the peel color variation with advancement of fruit maturation. In this work, we proposed Stage I: Intense green, Stage II: Green, Stage III: Green-Yellow, Stage IV: Intense yellow. This labeling was proposed based in Mexican lemon (Citrus aurantifolia Swingle) norm (NMX-FF-087-SCFI-2001, 2001). Lab essays were performed by triplicate.

\section{Extraction of essential oil}

The outline of the equipment used for extraction consisted of a two-neck angled round flask, in which a lime peel previously weighted were deposited; the flask was then placed in a heating mantle. Saturated steam enters through one opening and passes through the oil mixture. The steam-oil mixture then enters a condenser, where the condensate is recovered in a separating funnel, with the oil retained and the water drained. A total of $100 \mathrm{~g}$ of lime peel in its four stages of maturity was used with an extraction time of 30-35 min. The extraction using hexane was performed using a hexane-peel at a 1:2 w/v ratio and continuing maceration for $24 \mathrm{~h}$; the essence was extracted by distillation. The essays were performed by triplicate.

\section{Analysis of essential oil}

The extracted essences were placed in vials to quantify and analyze according the Mexican Norm NMX-F-062-1974 (1974) Mexican lemon essential oil (Citrus aurantiifolia (Christm.) Swingle distillate. The essence was injected into a GC Claurus 500 gas chromatograph coupled to a Claurus 500 MS mass spectrophotometer (Perkin-Elmer Inc., Wellesley, Massachusetts, USA). The column used was a capillary column $(30 \mathrm{~m} \times 0.25 \mathrm{~mm}$ i.d. $)$, coated with INNOWAX $(0.5 \mu \mathrm{m}$ phase thickness) (Agilent Technologies, Palo Alto, California, USA). Helium (99.999\% high purity) was used as the carrier gas (inlet pressure $82737 \mathrm{~Pa}(12 \mathrm{PSI})$ ) at a flow rate of $1.6667 \times$ $10^{-8} \mathrm{~m}^{3} \mathrm{~s}^{-1}\left(1 \mathrm{~mL} \mathrm{~min}^{-1}\right)$ (splitting ratio 10:1). The oven temperature was programmed from 60 (8 min-hold) to $250{ }^{\circ} \mathrm{C}$ (30 min-hold) at $5{ }^{\circ} \mathrm{C} \mathrm{min}^{-1}$ (Colecio-Juárez, 2007). The volume injected was $1 \mu \mathrm{L}$. The injector temperature was $220^{\circ} \mathrm{C}$. In the mass spectrophotometer, the temperatures of the ionization chamber and the transfer line were maintained at 180 and $200{ }^{\circ} \mathrm{C}$, respectively. The electron energy was $70 \mathrm{eV}$, and the mass range used was 30 to $450 \mathrm{~m} / \mathrm{z}$ (mass/charge number).

The essence chromatogram obtained was analyzed, and each peak was checked by determining the percent area on the chromatogram, the retention time, the spectrum and the base peak and then referring to the characteristic mass spectra of compounds listed on the National Institute of Standards and Technologies using the software Windows Search Program Version 2.0 Perkin Elmer.

\section{RESULTS AND DISCUSSION}

According to the physicochemical analysis (Table 1), the amount of juice, soluble solids and total sugars mainly increases with the stage of maturation, which is probably due to the biosynthetic processing or undergoing hydrolysis of polysaccharides occurring as the lime reaches its greatest size and weight in the maturity stages III and IV. As the concentration of soluble solids increased, the concentration of organic acids decreased and therefore the ratio ${ }^{\circ} \mathrm{Bx} / \%$ acidity increases (Louche et al., 2000). 
Table 1. Physicochemical characteristics of sweet lime (Citrus limetta) in different maturity stages.

\begin{tabular}{|c|c|c|c|c|c|}
\hline $\begin{array}{l}\text { Maturity } \\
\text { stage }\end{array}$ & $\begin{array}{c}\text { Fruit } \\
\text { weight }\end{array}$ & $\begin{array}{c}\text { Juice } \\
\text { volume }\end{array}$ & $\begin{array}{c}\text { Soluble } \\
\text { solids }\end{array}$ & Acidity & $\begin{array}{c}{ }^{\circ} \mathrm{Bx} / \% \\
\text { acidity } \\
\text { ratio }\end{array}$ \\
\hline & $\mathrm{g}$ & $\mathrm{mL}$ & ${ }^{\circ} \mathrm{Bx}$ & $\%$ citric acid & \\
\hline I & $67.45 \mathrm{a} \pm 6.56$ & $20.78 \mathrm{a} \pm 3.940$ & $7.11 \mathrm{a} \pm 0.485$ & $0.016 a \pm 0.0033$ & $444: 1$ \\
\hline II & $72.55 b \pm 8.72$ & $30.44 b \pm 6.064$ & $7.44 a b \pm 0.391$ & $0.012 \mathrm{a} \pm 0.0022$ & $620: 1$ \\
\hline III & $103.34 c \pm 12.05$ & $35.88 \mathrm{c} \pm 6.822$ & $7.94 b \pm 0.726$ & $0.009 \mathrm{a} \pm 0.0014$ & $882: 1$ \\
\hline IV & $94.70 d \pm 20.20$ & $36.71 \mathrm{c} \pm 9.320$ & $10.38 c \pm 0.485$ & $0.0067 \mathrm{a} \pm 0.0010$ & 1549:1 \\
\hline
\end{tabular}

\section{Extraction of essential oil}

The characteristics of the essential oil obtained by steamcarrying distillation and hexane at different stages of maturity are compared in Table 2 . The most essential oil is extracted when the lime is in the maturity stages I and II. The greatest quantity is found in stage I, exceeding $50 \%$ of the remaining steam distillation extractions and $20 \%$ of the extractions with hexane. This result is probably obtained because when the fruit is completely green, there are a high number of oil glands used by the plant as a defense against predators, with this number decreasing in the last stages of maturity (Smith et al., 2001). When hexane was used, a green-yellow coloration was observed in the extract due to the co-extraction of chlorophyll and other compounds that are of interest in the study; the sample undergoing steam distillation was colorless and practically free of undesirable compounds. An extraction time of $45 \mathrm{~min}$ using steam-carrying distillation was enough to recover most of the essential oil; the amount of time used for this procedure is lower than that reported by other authors, who recommend an extraction time of $2 \mathrm{~h}$ (Gil and Sáez, 2005). The refractive index reported is similar in both essences and this presents no significant variation through fruit ripening. However, the percentage evaporation residue makes a significant difference in both extractions, showing that values of the essential oil extracted by steam distillation in all stages of maturity were of $1.534 \%$ on average. Mexican norm establishes the average values of $0.2-2.2 \%$, so that lie within the allowable range, unlike the essential oil extracted with hexane whose average values of percentage evaporation residue were of $7.683 \%$ on average.

Table 2. Comparison between steam distillation and hexane extraction.

\begin{tabular}{|c|c|c|c|c|c|}
\hline \multicolumn{2}{|c|}{$\begin{array}{l}\text { Maturity } \\
\text { stage }\end{array}$} & Volume & Density & $\begin{array}{l}\text { Refraction } \\
\text { index }\end{array}$ & $\begin{array}{l}\text { Evaporation } \\
\text { residue }\end{array}$ \\
\hline & & $\mathrm{mL}$ & $\mathrm{g} \mathrm{n}$ & & 70 \\
\hline \multirow[t]{2}{*}{ I } & $\mathrm{S}$ & $1.460 \mathrm{a} \pm 0.461$ & $0.8656 \mathrm{a} \pm 0.020$ & $1.476 \mathrm{a} \pm 0.003$ & $1.534 \mathrm{a} \pm 0.139$ \\
\hline & $\mathrm{H}$ & $0.830 b \pm 0.034$ & $0.7425 b \pm 0.096$ & $1.477 b \pm 0.003$ & $7.683 b \pm 0.068$ \\
\hline \multirow[t]{2}{*}{ II } & $\mathrm{S}$ & $0.650 \mathrm{a} \pm 0.050$ & $0.8868 \mathrm{a} \pm 0.036$ & $1.477 \mathrm{a} \pm 0.004$ & $1.534 \mathrm{a} \pm 0.139$ \\
\hline & $\mathrm{H}$ & $0.770 b \pm 0.052$ & $0.6762 b \pm 0.036$ & $1.477 b \pm 0.000$ & $7.683 b \pm 0.068$ \\
\hline \multirow[t]{2}{*}{ III } & $\mathrm{S}$ & $0.590 \mathrm{a} \pm 0.017$ & $0.8470 \mathrm{a} \pm 0.022$ & $1.471 \mathrm{a} \pm 0.004$ & $1.534 \mathrm{a} \pm 0.139$ \\
\hline & $\mathrm{H}$ & $0.400 b \pm 0.104$ & $0.7770 b \pm 0.082$ & $1.477 b \pm 0.000$ & $7.683 b \pm 0.068$ \\
\hline \multirow[t]{2}{*}{ IV } & $\mathrm{S}$ & $0.260 c \pm 0.029$ & $0.8631 \mathrm{a} \pm 0.003$ & $1.472 \mathrm{a} \pm 0.004$ & $1.534 \mathrm{a} \pm 0.139$ \\
\hline & $\mathrm{H}$ & $0.282 \mathrm{c} \pm 0.042$ & $0.7297 b \pm 0.052$ & $1.477 b \pm 0.000$ & $7.683 b \pm 0.068$ \\
\hline
\end{tabular}

S: steam distillation; H: hexane extraction.

The established parameters in the Mexican norm: Density $=[0.855-0.863]$

Refraction index $=[1.4745-1.477]$ and $\%$ evaporation residue $=[0.2-2.2]$.

Values correspond to average value \pm standard deviation.

Values with different letter indicate significant differences between treatments according to Tukey test $(\mathrm{p}<0.005)$.

\section{Chromatographic analysis}

A total of 46 compounds were identified by mass spectrometry (Table 3). Most of these are terpenes, which are found in greater amounts than sesquiterpenes, aldehydes, ketones, phenols, and free acids. Alcohols and some terpenes show higher percentage areas in the maturity stages I and II. Maturity stage I showed the presence of $\alpha$-terpineol, a monoterpene that slows the peroxidation of linoleic acid (Foti and Ingold, 2003). The main component of the citrus peel oils is limonene, which appears in concentrations of $45 \%$ in lime up to 96\% in orange and grapefruit oil (Steuer et al., 2001); in this work, d-limonene showed a concentration level higher than $70 \%$, followed by bergamol $(8 \%)$,

Table 3. Area percent in compounds found in different maturity stages of Citrus limetta Risso.

\begin{tabular}{|c|c|c|c|c|}
\hline \multirow[b]{2}{*}{ Compound } & \multicolumn{4}{|c|}{ Maturity stages } \\
\hline & I & II & III & IV \\
\hline$\alpha$-Pinene & $0.77 \pm 0.06$ & $0.89 \pm 0.03$ & $0.82 \pm 0.05$ & $0.89 \pm 0.01$ \\
\hline Camphene & $0.03 \pm 0.01$ & $0.04 \pm 0.00$ & $0.04 \pm 0.00$ & $0.03 \pm 0.00$ \\
\hline$\beta$-Pinene & $8.63 \pm 0.00$ & $8.96 \pm 0.03$ & $7.62 \pm 0.01$ & $6.48 \pm 0.02$ \\
\hline Sabinene & $1.85 \pm 0.00$ & $2.12 \pm 0.00$ & $1.86 \pm 0.02$ & $0.93 \pm 0.00$ \\
\hline$\beta$-Myrcene & $1.15 \pm 0.05$ & $1.31 \pm 0.01$ & $1.43 \pm 0.01$ & $1.68 \pm 0.01$ \\
\hline d-Limonene & $66.8 \pm 0.04$ & $71.7 \pm 0.00$ & $74.4 \pm 0.00$ & $77.7 \pm 0.00$ \\
\hline Nonanal & - & - & $0.03 \pm 0.00$ & $0.04 \pm 0.00$ \\
\hline (Z) Sabinene hydrate & $0.02 \pm 0.00$ & $0.01 \pm 0.00$ & $0.01 \pm 0.00$ & $0.01 \pm 0.00$ \\
\hline Nonane & $0.09 \pm 0.00$ & $0.10 \pm 0.01$ & $0.10 \pm 0.00$ & $0.12 \pm 0.00$ \\
\hline Undecanal & $0.02 \pm 0.00$ & $0.03 \pm 0.01$ & - & - \\
\hline Linalool & $5.92 \pm 0.01$ & $3.61 \pm 0.01$ & $2.89 \pm 0.00$ & $1.98 \pm 0.00$ \\
\hline Camphor & - & $\operatorname{Tr}$ & $\operatorname{Tr}$ & - \\
\hline Bergamol & $12.3 \pm 0.05$ & $8.76 \pm 0.05$ & $8.23 \pm 0.05$ & $7.19 \pm 0.05$ \\
\hline Trans- $\alpha$-bergamotene & $0.36 \pm 0.08$ & $0.37 \pm 0.00$ & $0.36 \pm 0.00$ & $0.35 \pm 0.00$ \\
\hline Aromadendrene & $0.10 \pm 0.06$ & $0.10 \pm 0.00$ & $0.10 \pm 0.00$ & $0.10 \pm 0.03$ \\
\hline Terpinen-4-ol & - & $0.07 \pm 0.00$ & $0.05 \pm 0.01$ & $0.06 \pm 0.03$ \\
\hline Epi- $\beta$-santalene & - & $0.01 \pm 0.00$ & $0.01 \pm 0.01$ & $0.01 \pm 0.02$ \\
\hline Trans-sabinene hydrate & $0.07 \pm 0.00$ & - & - & - \\
\hline Farnesol & $0.06 \pm 0.00$ & $0.05 \pm 0.06$ & $0.06 \pm 0.02$ & $0.06 \pm 0.00$ \\
\hline Isopinocarveol & $0.13 \pm 0.01$ & - & - & - \\
\hline Terpineol acetate & $0.09 \pm 0.07$ & $0.09 \pm 0.02$ & $0.08 \pm 0.01$ & $0.09 \pm 0.00$ \\
\hline$\alpha$-Terpineol & $0.33 \pm 0.05$ & - & - & - \\
\hline Neryl acetate & $0.28 \pm 0.08$ & $0.28 \pm 0.02$ & $0.26 \pm 0.03$ & $0.34 \pm 0.03$ \\
\hline Neral & $0.2 \pm 0.02$ & $0.2 \pm 0.01$ & - & - \\
\hline Geranyl acetate & - & $0.26 \pm 0.00$ & $0.10 \pm 0.05$ & $0.20 \pm 0.02$ \\
\hline Geranial & - & $0.18 \pm 0.00$ & $0.18 \pm 0.00$ & $0.22 \pm 0.00$ \\
\hline Cis-geraniol & $0.16 \pm 0.00$ & $0.18 \pm 0.00$ & $0.16 \pm 0.03$ & $0.16 \pm 0.01$ \\
\hline $\begin{array}{l}\text { 1-Cyclohexen-1 } \\
\text {-methanol, } \\
\text { 4-1 methylenil acetate }\end{array}$ & - & - & $0.01 \pm 0.02$ & 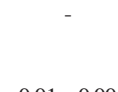 \\
\hline Octal cyclopropene & - & --- & $0.01 \pm 0.01$ & $0.01 \pm 0.00$ \\
\hline Cis-myrtanol & - & $0.01 \pm 0.00$ & $0.01 \pm 0.01$ & $0.02 \pm 0.00$ \\
\hline Perillal & - & $0.01 \pm 0.00$ & - & $0.01 \pm 0.00$ \\
\hline 2-Tridecen-1-ol & - & - & $\operatorname{Tr}$ & $\operatorname{Tr}$ \\
\hline 3-Cyclohexen-1-ol & - & - & $\operatorname{Tr}$ & $\operatorname{Tr}$ \\
\hline 2-Cyclohexyl-dodecane & - & $\operatorname{Tr}$ & - & - \\
\hline $\begin{array}{l}\text { Bicyclo }(2,2,1) \text { Heptane } \\
\text { 2,2diethyl-3-methyl }\end{array}$ & $0.09 \pm 0.00$ & $0.08 \pm 0.00$ & - & - \\
\hline P-menth-1-en-8-ol & $0.34 \pm 0.02$ & $0.31 \pm 0.01$ & $0.21 \pm 0.03$ & $0.21 \pm 0.01$ \\
\hline$\beta$-Bisabolol & $0.60 \pm 0.05$ & $0.60 \pm 0.01$ & $0.60 \pm 0.05$ & $0.059 \pm 0.00$ \\
\hline Carveol & $\operatorname{Tr}$ & $0.13 \pm 0.01$ & - & - \\
\hline$\alpha$-Farnesene & $\operatorname{Tr}$ & - & - & - \\
\hline$\alpha$-Bisabolol & $0.02 \pm 0.00$ & $0.03 \pm 0.00$ & $0.02 \pm 0.00$ & $0.03 \pm 0.00$ \\
\hline$\beta$-Farnesene & $\operatorname{Tr}$ & $\operatorname{Tr}$ & $\operatorname{Tr}$ & $0.01 \pm 0.00$ \\
\hline Trans- $\beta$-santalol & $0.01 \pm 0.00$ & - & - & - \\
\hline$\alpha$-Santalol & - & $0.01 \pm 0.00$ & $0.01 \pm 0.00$ & $0.02 \pm 0.00$ \\
\hline Isopropyl palmitate & - & $0.01 \pm 0.00$ & - & - \\
\hline$\beta$-Santalene & $\operatorname{Tr}$ & $0.01 \pm 0.00$ & $0.01 \pm 0.00$ & $0.01 \pm 0.00$ \\
\hline $\begin{array}{l}\text { Cyclopropamethanol, } \\
\alpha, 2 \text {-dimethyl-2-4- } \\
\text { methyl-3-pentanyl }\end{array}$ & $\operatorname{Tr}$ & $0.01 \pm 0.00$ & $0.01 \pm 0.00$ & $0.02 \pm 0.00$ \\
\hline
\end{tabular}


$\beta$-pinene (7.62\%), linalool (2.89\%), $\alpha$-pinene $(0.82 \%)$ and the remaining compounds, which number over 40 $(2.73 \%)$. The main flavor components of the fresh lime are limonene, $\alpha$-terpineol, 4-terpineol, neryl acetate, $\beta$-pinene, $\beta$-bisabolene, neral, citral, geranial 1,4 cineole, 1,8 cineole, $p$-cymene, $\alpha$-bergamotene, valencene, and d-germacrene (Yadav et al., 2004); the first seven compounds were found in this work.

The compounds found in $C$. limetta are compared with the compounds reported in other varieties (Table 4) (Shaw et al., 2000; Steuer et al., 2001; Yadav et al., 2004; Mahmud et al., 2009; Bousbia et al., 2009). The $\mathrm{d}$-limonene, $\beta$-pinene, $\beta$-myrcene, $\alpha$-pinene, $\beta$-bisabolol and $\alpha$-terpineol levels are in the range reported by the majority of authors. The linalool, sabinene, and bergamol show similar concentration levels with those found for other reported varieties. Sabinene has antimicrobial and antioxidant properties; its concentration in lemon is $1-2 \%$, similar to the amount found in this work.
Previous research described, a practical and convenient synthesis starting from linalool via bergamol or linalyl acetate (Berger, 2007). Geraniol, a compound related to the fruit's aroma, with a citrus-like and menthollike odor, possesses anticancer activity and can reduce the growth of colon cancer cells by up to $70 \%$ (Berger, 2007). Rammanee and Hongpattarakere (2011) report that essential oils from tropical citrus epicarps have inhibitory activities against Aspergillus fungi. In sweet lime, geraniol increased with maturity but was not found in stage I; however, it is found in greater quantity than in other varieties. The alcohol $\beta$-bisabolol was found in lime for the first time in the year 2004 (Yadav et al., 2004); in this study, it was found with a concentration that was $50 \%$ higher. There were no reported values for the content of nonanal and undecanal; these aliphatic aldehydes are related to the quality of citrus (Stuart et al., 2001) and have aromatic properties, first described as having citrus-like and soapy notes (Berger,

Table 4. Comparison between Citrus limetta in this work and other authors (\% area percent).

\begin{tabular}{|c|c|c|c|c|c|c|}
\hline & $\begin{array}{c}\text { Shaw et al., } \\
2000\end{array}$ & $\begin{array}{c}\text { Steuer et al., } \\
2001\end{array}$ & $\begin{array}{l}\text { Yadav et al., } \\
2004\end{array}$ & $\begin{array}{c}\text { Mahmud et } \\
\text { al., } 2009\end{array}$ & $\begin{array}{l}\text { Bousbia et al., } \\
2009\end{array}$ & This work \\
\hline Compounds & $\begin{array}{l}\text { Wild lime } \\
\text { Microcitrus } \\
\text { inodora }\end{array}$ & $\begin{array}{c}\text { Lime } \\
\text { commercial } \\
\text { oil }(\mathrm{MCI})\end{array}$ & $\begin{array}{l}\text { Citrus aurantifolia } \\
\text { (Chrism.) } \\
\text { Swingle }\end{array}$ & $\begin{array}{l}\text { Citrus acida } \\
\text { var. sour } \\
\text { lime }\end{array}$ & $\begin{array}{l}\text { Citrus aurantifolia } \\
\text { (Chrism.) } \\
\text { Swingle }\end{array}$ & Citrus limetta \\
\hline d-Limonene & 68.50 & 49.9 & 75.5 & & 63.44 & $71.70 \pm 0.00$ \\
\hline$\beta$-Pinene & & 4.2 & 32.1 & & 13.09 & $8.96 \pm 0.03$ \\
\hline Bergamol & & & & 2.37 & & $12.30 \pm 0.05$ \\
\hline Linalool & 0.13 & & 1.3 & & 0.36 & $3.61 \pm 0.01$ \\
\hline Sabinene & 0.11 & 0.5 & & & & $2.12 \pm 0.00$ \\
\hline$\beta$-Myrcene & 1.44 & 1.3 & & & 1.46 & $1.31 \pm 0.01$ \\
\hline$\alpha$-Pinene & 0.31 & 1.4 & 6.8 & & 1.94 & $0.89 \pm 0.03$ \\
\hline$\beta$-Bisabolol & & & 0.4 & & & $0.60 \pm 0.05$ \\
\hline$\beta$-Bisabolene & & & & 5.07 & 0.81 & $0.60 \pm 0.01$ \\
\hline Trans- $\alpha$-bergamotene & & & 4.7 & & 0.54 & $0.37 \pm 0.00$ \\
\hline$\alpha$-Terpineol & 0.02 & 6.2 & 13.3 & & 0.37 & $0.33 \pm 0.05$ \\
\hline Neryl acetate & & & 0.5 & & 0.60 & $0.28 \pm 0.02$ \\
\hline Geranyl acetate & & & 0.6 & 2.83 & 0.60 & $0.26 \pm 0.00$ \\
\hline Neral & $\operatorname{Tr}$ & & 1.8 & & 1.55 & $0.20 \pm 0.02$ \\
\hline Geranial & $\operatorname{Tr}$ & & 4.1 & & 2.05 & $0.18 \pm 0.00$ \\
\hline Cis-geraniol & & & & & 0.07 & $0.18 \pm 0.00$ \\
\hline Isopinocarveol & & & & & & $0.13 \pm 0.01$ \\
\hline Citronellal & & & & & 0.05 & $0.13 \pm 0.00$ \\
\hline nonane & & & & & & $0.10 \pm 0.01$ \\
\hline Aromadendrene & & & & & & $0.10 \pm 0.00$ \\
\hline Epi- $\beta$-santalene & & & & & & $0.10 \pm 0.00$ \\
\hline$\alpha$-Terpineol acetate & & & & & & $0.09 \pm 0.02$ \\
\hline Terpinen-4-ol & & & 6.8 & & 0.19 & $0.07 \pm 0.00$ \\
\hline Trans-sabinene hydrate & & & & & & $0.07 \pm 0.00$ \\
\hline Farnesol & & & & 1.25 & & $0.05 \pm 0.06$ \\
\hline Camphene & & & & & & $0.04 \pm 0.00$ \\
\hline Undecanal & & & & & & $0.03 \pm 0.01$ \\
\hline Nonanal & & & & & - & $0.03 \pm 0.00$ \\
\hline$\alpha$-Bisabolol & & & 0.2 & & 0.02 & $0.03 \pm 0.00$ \\
\hline Myrcenil acetate & & & & & & $0.01 \pm 0.03$ \\
\hline (Z) Sabinene hydrate & & & & & & $0.01 \pm 0.00$ \\
\hline Octil ester & & & & & & $0.01 \pm 0.00$ \\
\hline 1-Cyclohexen-1-methanol, 4-1 methylenil acetate & & & & & & $0.01 \pm 0.00$ \\
\hline Trans-nerolidol & & & 14.3 & & & $0.01 \pm 0.00$ \\
\hline Octal cyclopropane & & & & & & $0.01 \pm 0.00$ \\
\hline Cis-myrtanol & & & & & & $0.01 \pm 0.00$ \\
\hline Aldehyde peril & $\operatorname{Tr}$ & & & & & $0.01 \pm 0.00$ \\
\hline$\beta$-Farnesene & & & 0.6 & & 0.06 & $0.01 \pm 0.00$ \\
\hline Trans- $\beta$-santalol & & & & & & $0.01 \pm 0.00$ \\
\hline Isopropyl palmitate & & & & & & $0.01 \pm 0.00$ \\
\hline$\beta$-Santalene & & & 0.2 & & & $0.01 \pm 0.00$ \\
\hline Camphor & & & & & & 0.001 \\
\hline$\alpha$-Farnesene & & & & & & 0.001 \\
\hline
\end{tabular}


2007). Other compounds, such as aromadendrene and camphene, are not reported; camphene has a role in the digestion of fat through increasing bile secretion (Berger, 2007). Compounds with values of under $0.03 \%$ cannot be compared; camphor and $\alpha$-farnesene show area percents of $0.001 \%$, and this result indicates that the sensitivity of the column and the chromatographic method are important in the separation and identification of compounds.

\section{CONCLUSIONS}

During the characterization of the essential oil of sweet lime (Citrus limetta), a higher amount of essential oil was found in maturity stages I and II, which is probably due the greater number of essential oil-producing glands present at these stages. Extraction with hexane produced a higher yield of essential oil, but, in addition to extracting the essence, this approach also extracted compounds such as waxes, pigments and polysaccharides. Therefore, the steam distillation technique provides an essence of higher purity. Using chromatography, compounds with values of 0.001 , such as camphene, were identified and isolated.

\section{ACKNOWLEDGEMENTS}

We gratefully acknowledge the financial support of CONCYTEG (Guanajuato State Government) via grant 05-09-k117-061.

\section{Caracterización de compuestos volátiles en aceite} esencial de lima dulce (Citrus limetta Risso). El aceite esencial de frutos cítricos contiene componentes de características sensoriales agradables que son apreciadas en las industrias alimentaria, farmacéutica y de cosméticos. En el caso de la lima dulce (Citrus limetta Risso), es necesaria la caracterización de los componentes de su aceite esencial para identificar usos potenciales de este fruto. El aceite esencial de lima dulce se obtuvo a partir del flavedo de lima en cuatro etapas de maduración diferentes. Se utilizó destilación por arrastre de vapor y se comparó con la extracción con hexano. La identificación de los componentes en el aceite esencial se realizó por cromatografía de gases y espectrometría de masas. Se encontró un total de 46 componentes en el aceite esencial de lima, entre los cuales la mayor concentración de compuestos presentes son aldehídos como el limoneno. Linalol, sabineno y bergamol fueron más abundantes que en otras variedades. El mejor método de extracción fue la destilación al vapor, y las concentraciones en la etapa III de la parte terpénica principal fueron d-limoneno $74.4 \%$, bergamol $8.23 \%$, y $\beta$-pineno $7.62 \%$.

Palabras clave: lima dulce, Citrus limetta, aceite esencial, destilación por arrastre de vapor, estados de maduración.

\section{LITERATURE CITED}

Anwar, F., R. Naseer, M.I. Bhanger, S. Ashraf, F.N. Talpur, and F.A. Aladeduny. 2008. Physico-chemical characteristics of citrus seeds and seed oils from Pakistan. Journal of the American Oil Chemists Society 85:321-330.

AOAC. 1990. Official methods of analysis. $15^{\text {th }}$ ed. Association of Official Analytical Chemists (AOAC), Arlington, Virginia, USA.

Atti-Santos, A.C., M. Rossato, L. Atti-Serafini, E. Casset, and P. Moyna. 2005. Extraction of essential oils from Lime (Citrus latifolia Tanaka) by hydrodistillation and supercritical carbon dioxide. Brazilian Archives of Biology and Technology 48:156160.

Berger, R.G. (ed.) 2007. Flavours and fragrances. Chemistry, bioprocessing and sustainability. p. 118-133, 329. SpringerVerlag, Berlin, Heidelberg, Germany.

Bousbia, N., V.M. Abert, M.A. Ferhat, B.Y. Meklati, and F. Chemat. 2009. A new process for extraction of essential oil from Citrus peels: Microwave hydrofusion and gravity. Journal of Food Engineering 90:409-413.

Colecio-Juárez, M.C. 2007. Caracterización de los principales componentes del aceite esencial de lima dulce (Citrus limetta). M.S. Thesis (in Spanish). Instituto Tecnológico de Celaya, Celaya, México.

Foti, C.M., and K.U. Ingold. 2003. Mechanism of inhibition of lipid peroxidation by terpinene, an usual and potentially useful hydrocarbon antioxidant. Journal of Agriculture and Food Chemistry 51:2758-2765.

Frizzo, D.C., D. Lorenzo, and E. Dellacassa. 2004. Composition and seasonal variation of the essential oils from two mandarin cultivars of southern Brazil. Journal of Agriculture and Food Chemistry 52:3036-3041.

Gil, P.E., and V.A. Sáez. 2005. Evaluación a escala de planta piloto del proceso industrial para la obtención de aceite esencial de cardamomo, bajo la filosofía de "Cero emisiones". Universidad Escuela de Administración y Finanzas y Tecnologías EAFIT, Medellín, Colombia.

JAOAC. 1983. Solids (soluble) in citrus fruit juices. Official Methods of Analysis. Journal of Association of Official Analytical Chemists (JAOAC), Washington D.C., USA.

Kondo, M., M. Goto, A. Kodama, and T. Hirose. 2000. Fractional extraction by supercritical carbon dioxide for the deterpenation of bergamot oil. Industrial and Engineering Chemistry Research 39:4745-4748

Louche, M.M., F. Luro, E.M. Gaydou, and J.C. Lesage. 2000. Phlorin screening in various citrus species and varieties. Journal of Agriculture and Food Chemistry 48:4728-4733.

Mahmud, S., M. Saleem, S. Siddique, R. Ahmed, R. Khanum, and Z. Perveen. 2009. Volatile components, antioxidant and antimicrobial activity of Citrus acida var. sour lime peel oil. Journal of Saudi Chemical Society 13:195-198.

Mazen, K.T. 2002. Molecular regulation of plant monoterpene biosynthesis in relation to fragrance. 159 p. Thesis. Wageningen Universiteit, Wageningen, The Netherlands.

Misharina, T.A., and A.L. Samusenki. 2008. Antioxidant properties of essential oils from lemon, grapefruit, coriander, clove and their mixtures. Applied Biochemistry and Microbiology 45:438-442.

Mondello, L., A. Casilli, Q.P. Tranchida, L. Cicero, P. Dugo, and G. Dugo. 2003. Comparison of fast and conventional GC analysis for citrus essential oils. Journal of Agriculture and Food Chemistry 51:5602-5606

Murdock, D.L., and W.E. Allen. 1960. Germicidal effect of orange peel oil and d-limonene in water and orange juice, fungicidal properties against yeast. Food Technology 14:441-445.

Nicolosi, E. 2007. Origin and taxonomy. Chapter III. In Khan, I.A. (ed.) Citrus genetics, breeding and biotechnology. CABI International, Wallingford, UK.

NMX-F-062-1974. 1974. Norma mexicana: Aceite esencial de limón mexicano (Citrus aurantifolia Swingle) destilado. Dirección General de Normas, Secretaria de Economía, México. 
NMX-FF-087-SCFI-2001 2001. Norma mexicana: Productos alimenticios no industrializados para uso humano - fruta fresca limón mexicano (Citrus aurantifolia Swingle) - especificaciones. Dirección General de Normas, Secretaría de Economía, México.

Perez, Y.Y., E. Jiménez-Ferrer, D. Alonso, C.A. BotelloAmaro, and A. Zamilpa. 2010. Citrus limetta leaves extract antagonizes the hypertensive effect of angiotensin II. Journal of Ethnopharmacology 128:611-614

Rammanee, K., and T. Hongpattarakere. 2011. Effects of tropical citrus essential oils on growth, aflatoxin production, and ultrastructure alterations of Aspergillus flavus and Aspergillus parasiticus. Food and Bioprocess Technology 4:1050-1059.

Roger, D., V.M. Edwards, and W.A. Moats. 1970. Antimicrobial action of some citrus fruit oils on selected food-borne bacteria. Applied Microbiology 19:27-31.

Shaw, P.E., M.G. Moshonas, and K.D. Bowman. 2000. Volatile constituents in juice and oil of Australian wild lime (Microcitrus inodora). Phytochemistry 53:1083-1086.
Smith, D.C., S. Forland, E. Bachanos, M. Matejka, and V. Barrett. 2001. Qualitative analysis of citrus fruit extracts by GC/MS: an undergraduate experiment. Chemical Educator 6:28-31.

Steuer, B., H. Schulz, and B. Läger. 2001. Classification and analysis of citrus oils by NIR spectroscopy. Food Chemistry 72:113-117.

Stuart, G.R., D. Lopes, and V. Oliveira. 2001. Deterpenation of Brazilian orange peel oil by vacuum distillation. Journal of the American Oil Chemists Society 78:1041-1044.

Yadav, A.R., A.S. Chauhan, M.N. Rekha, L.J.M. Rao, and R.S Ramteke. 2004. Flavour quality of dehydrated lime [Citrus aurantifolia (Christm.) Swingle]. Food Chemistry 85:59-62.

Yamasaki, Y., H. Kunoh, H. Yamamoto, and K. Akimitsu. 2007. Biological roles of monoterpene volatiles derived from rough lemon (Citrus jambhiri Lush) in citrus defense. Journal of General Plant Pathology 73:168-179. 